\title{
Editorial
}

\section{High mobility group box-1 protein as a tumor necrosis factor-independent therapeutic target in rheumatoid arthritis}

\author{
Richard S Goldstein
}

Department of Emergency Medicine and The Feinstein Institute for Medical Research, North Shore University Hospital, Community Drive, Manhasset, NY 11030, USA

Corresponding author: Richard S Goldstein, rgoldst2@nshs.edu

Published: 2 June 2008

This article is online at http://arthritis-research.com/content/10/3/111

Arthritis Research \& Therapy 2008, 10:111 (doi:10.1186/ar2427)

c) 2008 BioMed Central Ltd

See related research article by Sundberg et al., http://arthritis-research.com/content/10/2/R33

\begin{abstract}
Rheumatoid arthritis (RA) remains a prevalent disease worldwide that causes significant morbidity and mortality despite recent therapeutics. High mobility group box-1 (HMGB1) protein, originally appreciated as an intranuclear DNA binding protein, has been implicated as an integral mediator in the pathogenesis of animal arthritides and RA disease in humans. Our current understanding of HMGB1 has promoted the development of targeting therapies that have improved outcomes in animal models of inflammation. In the previous issue of Arthritis Research \& Therapy, Sundberg and colleagues address, for the first time in a prospective cohort study, whether HMGB1 expression is dependent upon tumor necrosis factor activity in patients with RA.
\end{abstract}

\section{Introduction}

Rheumatoid arthritis (RA) is an autoimmune chronic destructive polyarthropathy that has a worldwide prevalence of $0.5 \%$ to $1 \%$, and an incidence of 3 cases per 10,000 persons annually. Over-expression of pro-inflammatory cytokines, including tumor necrosis factor (TNF) and interleukin (IL)-1, play a critical role in the pathogenesis of RA and is the basis for RA targeting strategies in recent years. In the previous issue of Arthritis Research \& Therapy, Sundberg and colleagues [1] set forth to determine whether anti-TNF therapy influences synovial and extracellular high mobility group box-1 (HMGB1) protein expression in patients with RA.

Anti-inflammatory medications, disease modifying agents, and biological agents, including anti-TNF and anti-IL-1 antibodies, are the current mainstay of treatment and provide significant clinical improvement in many patients. Cytokine neutralizing agents, administered either alone or in combination with disease modifying agents, ameliorate disease symptoms and prevent progressive joint damage [2-4]. Despite these improvements, there remain patients who are unresponsive to anti-TNF therapy, indicating a considerable need for novel therapeutics that are independent of TNF activity.

\section{HMGB1 background}

HMGB1 has been implicated as a necessary and sufficient mediator in experimental arthritis [5-7]. HMGB1 was originally discovered as a DNA binding protein that facilitates DNA replication and repair. Once released extracellularly during inflammation by macrophages and other immune cells, it functions as a pro-inflammatory cytokine, like TNF, with pleiotropic activity. HMGB1 induces endothelial cytokine expression, causes epithelial barrier dysfunction, and activates macrophages to release pro-inflammatory mediators, including TNF, IL-1 $\alpha$, IL-6, and macrophage inflammatory protein$1 \alpha$ [8]. TNF release after stimulation of HMGB1 is significantly delayed compared with lipopolysaccharide-induced TNF release. Targeting the activity of HMGB1 using neutralizing antibodies confers protection in animal models of inflammation even when administered 24 hours after the onset of injury [9]. The promulgation of HMGB1 research has encouraged investigators to define its role in other inflammatory diseases, including RA.

\section{HMGB1 and rheumatoid arthritis}

HMGB1 has been found to have an integral role in the pathogenesis of arthritis. HMGB1 has been detected in significantly higher concentrations in the synovial fluid of RA patients compared to patients with osteoarthritis [5]. Immunohistochemical staining for HMGB1 in synovial tissue obtained from animals with collagen-induced arthritis reveals significant HMGB1 expression extracellularly and in the cytoplasm of macrophages and synoviocytes [6]. Synovial fluid

HMGB1 = high mobility group box-1; IL = interleukin; RA = rheumatoid arthritis; rHMGB1 = recombinant high mobility group box-1; TNF = tumor necrosis factor. 
macrophages express receptor for advanced glycation end products, and release TNF, IL-1 $\beta$, and IL- 6 upon stimulation with HMGB1 [5]. Intra-articular injection of recombinant HMGB1 (rHMGB1) induces arthritis in animals and shares key histological features observed in RA, including pannus formation, synovial membrane hypertrophy, and mononuclear cell predominance within synovial tissue [7]. The injection of rHMGB1 results in mild to moderate synovitis and may persist for at least 28 days. The induction of arthritis by rHMGB1 is primarily mediated by $\mathrm{IL}-1$ as confirmed by the absence of arthritis in IL-1 receptor-deficient mice after rHMGB1 administration [7]. Systemic administration of either neutralizing HMGB1 antigen-affinity purified polyclonal antibodies or the anti-inflammatory domain of HMGB1, termed the A-box protein, significantly reduced mean arthritis scores, disease-induced weight loss, and the histological severity of arthritis in an animal model of collagen-induced arthritis [6]. The presence of HMGB1 in arthritis models, the recapitulation of arthritis upon rHMGB1 administration, and the improvement of disease after HMGB1 inhibition implicate HMGB1 as a key mediator and potential therapeutic target in RA.

\section{HMGB1 as a novel therapeutic}

The recent article from Sundberg and colleagues [1] studies the relationship between systemic TNF blockade and synovial expression of HMGB1. Arthroscopy samples were obtained 1 to 21 days before and 8 to 10 weeks after initiation of antiTNF monoclonal antibody (infliximab) treatment. Cytoplasmic and extracellular expression of HMGB1 decreased in five patients, remained unchanged in one, and increased in three, rendering the authors' results statistically insignificant. HMGB1 mRNA expression remained unchanged after infliximab therapy as indicated by only two of the six patients studied by RTPCR having decreased HMGB1 mRNA levels. In addition, no correlation was observed between clinical response and the direction of change of HMGB1 expression. The authors concluded that their results reveal an unaffected expression of HMGB1 in synovia from patients with RA before and during TNF blockade with infliximab [1].

In corroboration with the authors' findings, a recent study by my colleagues and I revealed elevated serum levels of HMGB1 in RA patients, seven (>50\%) of whom were receiving anti-TNF therapy [10]. Recent experimental evidence has revealed that in addition to TNF, both $\mathrm{IL}-1$ and interferon- $\gamma$ induce HMGB1 release from activated macrophages. These data support the possibility that redundant mechanisms may contribute to HMGB1 signaling and that its activity might be independent of TNF during chronic inflammation.

Despite notable findings from the current study by Sundberg and colleagues, however, inherent limitations of the experimental design exist. First, it is difficult to derive powerful correlations given the relatively small patient cohort. Secondly, approximately $30 \%$ of patients had disease duration greater than or equal to 10 years. Furthermore, the study was confined to specimens from a single joint and sampling of joint tissue may be problematic given regional variation. Therefore, additional studies are required to further establish the relationship of HMGB1 and TNF in patients with RA.

The present study supports the hypothesis that HMGB1 release is independent of TNF activity in patients with RA. If reproduced in larger clinical trials then, together with the growing body of preclinical work, the development of antiHMGB1 antibodies as an experimental therapeutic for future study is warranted.

\section{Competing interests}

The author declares that they have no competing interests.

\section{References}

1. Sundberg E, Grundtman C, Klint E, Lindberg J, Ernestam S Ulfgren K, Harris H, Andersson U: Systemic TNF blockade does not modulate synovial expression of the proinflammatory mediator HMGB1 in rheumatoid arthritis patients - a prospective clinical study. Arthritis Res Ther 2008, 10:R33.

2. Maini R, St Clair EW, Breedveld F, Furst D, Kalden J, Weisman M, Smolen J, Emery P, Harriman G, Feldmann M, Lipsky P: Infliximab (chimeric anti-tumour necrosis factor $\alpha$ monoclonal antibody) versus placebo in rheumatoid arthritis patients receiving concomitant Methotrexate: a randomized phase III trial. Lancet 1999, 354:1932-1939.

3. Lipsky PE, van der Heijde DM, St Clair EW, Furst DE, Breedveld FC, Kalden JR, Smolen JS, Weisman M, Emery P, Feldmann M, Harriman GR, Maini RN; Anti-Tumor Necrosis Factor Trial in Rheumatoid Arthritis with Concomitant Therapy Study Group: Infliximab and methotrexate in the treatment of rheumatoid arthritis. New Engl J Med 2000, 343:1594-1602.

4. Weinblatt ME, Kremer JM, Bankhurst AD, Bulpitt KJ, Fleischmann RM, Fox RI, Jackson CG, Lange M, Burge DJ: A trial of etanercept, a recombinant tumor necrosis factor receptor:Fc fusion protein, in patients with rheumatoid arthritis receiving Methotrexate. New Eng J Med 1999, 340:253-259.

5. Taniguchi N, Kawahara K, Yone K, Hashiguchi T, Yamakuchi M, Goto M, Inoue K, Yamada S, ljiri K, Matsunaga S, Nakajima T, Komiya S, Maruyama I: High mobility group box chromosomal protein 1 plays a role in the pathogenesis of rheumatoid arthritis as a novel cytokine. Arthritis Rheum 2003, 48:971-981.

6. Kokkola R, Li J, Sundberg E, Aveberger AC, Palmblad K, Yang H, Tracey KJ, Andersson U, Harris HE: Successful treatment of collagen-induced arthritis in mice and rats by targeting extracellular high mobility group box chromosomal protein 1 activity. Arthritis Rheum 2003, 48:2052-2058.

7. Pullerits R, Jonsson IM, Verdrengh M, Bokarewa M, Andersson U, Erlandsson-Harris $\mathrm{H}$, Tarkowski A: High mobility group box chromosomal protein 1, a DNA binding cytokine, induces arthritis. Arthritis Rheum 2003, 48:1693-1700.

8. Andersson U, Wang $\mathrm{H}$, Palmblad $\mathrm{K}$, Aveberger $\mathrm{AC}$, Bloom $\mathrm{O}$, Erlandsson-Harris $H$, Janson A, Kokkola R, Zhang M, Yang $H$, Tracey KJ: High mobility group 1 protein (HMG-1) stimulates proinflammatory cytokine synthesis in human monocytes. J Exp Med 2000, 192:565-570.

9. Wang $\mathrm{H}$, Bloom $\mathrm{O}$, Zhang $\mathrm{M}$, Vishnubhakat JM, Ombrellino $\mathrm{M}$, Che J, Frazier A, Yang H, Ivanova S, Borovikova L, Manogue KR, Faist E, Abraham E, Andersson J, Andersson U, Molina PE, Abumrad NN, Sama A, Tracey KJ: HMG-1 as a late mediator of endotoxin lethality in mice. Science 1999, 285:248-251.

10. Goldstein RS, Bruchfeld A, Yang L, Qureshi AR, GallowitschPuerta M, Patel NB, Huston BJ, Chavan S, Rosas-Ballina M, Gregersen PK, Czura CJ, Sloan RP, Sama AE, Tracey KJ: Cholinergic anti-inflammatory pathway activity and high mobility group box-1 (HMGB1) serum levels in patients with rheumatoid arthritis. Mol Med 2007, 13:210-215. 